\title{
PENGARUH PENDEKATAN BERMAIN TERHADAP AKTIVITAS GERAK SISWA DALAM MENGIKUTI MATA PELAJARAN PENDIDIKAN JASMANI (Studi pada Siswa Kelas VII SMP Negeri 3 Trienggadeng)
}

\author{
M. Diah \\ SMP Negeri 3 Trienggadeng \\ Email. mdiahdiahsmp@gmail.com
}

\begin{abstract}
Abstrak
Jasmani pada dasarnya merupakan bagian penting dari sistem pendidikan secara keseluruhan. Oleh karena itu pelaksanaan pendidikan jasmani harus diarahkan pada pencapaian tujuan tersebut. Dalam proses pembelajaran pendidikan jasmani guru harus dapat mengajarkan berbagai keterampilan dasar, sehingga guru dituntut untuk lebih kreatif dalam memberikan mata pelajaran pendidikan jasmani. Seorang guru harus bisa menciptakan sesuatu yang baru atau memodifikasi yang sudah ada untuk dapat disajikan semenarik mungkin sehingga anak didik merasa senang ketika mengikuti pelajaran pendidikan jasmani. Dalam pelaksanaan proses pelajaran pendidikan jasmani, pemberian modifikasi pembelajaran melalui pendekatan bermain adalah salah satu upaya yang bisa dilakukan. Dalam penelitian dikaji tentang pengaruh pendekatan bermain terhadap peningkatan aktivitas gerak siswa pada siswa kelas VII SMP Negeri 3 Trienggadeng .Tujuan penelitian ini adalah: (1) Untuk mengetahui apakah melalui pendekatan bermain dapat meningkatkan aktivitas gerak siswa dalam mengikuti pembelajaran pendidikan jasmani pada siswa kelas VII SMP Negeri 3 Trienggadeng (2) Untuk mengetahui seberapa besar peningkatan aktivitas gerak siswa dala mengikuti pembelajaran pendidikan jasmani melalui pendekatan bermain pada siswa kelas VII SMP Negeri 3 Trienggadeng. Jenis penelitian yang digunakan dalam penelitian ini adalah penelitian eksperimen semu dengan menggunakan pendekatan kuantitatif. Di dalam penelitian ini terdapat dua variabel yang terdiri dari variabel bebas yaitu aktivitas gerak dan variabel terikat yaitu pendekatan bermain. Instrumen penelitian yang digunakan dalam penelitian menggunakan pedometer. Populasi dalam penelitian ini adalah siswa SMP Negeri 3 Trienggadeng, sampel diambil dengan menggunakan teknik cluster random sampling sebanyak 33 siswa kelas VII. Analisis data menggunakan t-test untuk sampel sejenis.Berdasarkan hasil penelitian maka dapat diketahui nilai rata-rata dan standar deviasi hasil belajar aktivitas gerak antara pre-test dan post-test. Rata-rata hasil belajar aktifitas gerak siswa pada pre-test adalah 840,94 dengan standar deviasi 58,787. Post-test didapat rata-rata hasil belajar aktifitas gerak siswa adalah 1456,67 dengan standar deviasi 168,353. Terlihat nilai mean perbedaan antara pre-test dan post-test adalah 615,727 dengan standar deviasi 182,971. Berdasarkan hasil uji statistik didapatkan nilai 0,000 maka dapat disimpulkan ada perbedaan yang signifikan antara pre-test dan post-test adalah sebesar $73,2 \%$. Jadi pendekatan bermain memberikan pengaruh yang signifikan terhadap peningkatan aktivitas gerak siswa pada siswa kelas VII SMP Negeri 3 Trienggadeng.
\end{abstract}

Kata kunci: pendekatan bermain, hasil belajar dan aktifitas gerak

\begin{abstract}
Physical education is basically an important part of the education system as a whole. Therefore the implementation of physical education must be directed at achieving that goal. In the process of learning physical education the teacher must be able to teach various basic skills, so that
\end{abstract}


teachers are required to be more creative in providing physical education subjects. A teacher must be able to create something new or modify existing ones to be presented as attractive as possible so that students feel happy when attending physical education lessons. In carrying out the process of physical education learning, giving learning modifications through a play approach is one of the efforts that can be done. In the study studied the influence of the play approach on increasing student motion activity in class VII students of SMP Negeri 3 Trienggadeng. The purpose of this study were: (1) To find out whether through the play approach can improve students' movement activities in attending physical education learning in class VII SMP Negeri 3 Trienggadeng (2) To find out how much the increase in motion activity of students in participating in physical education learning through the approach of playing on class VII students of SMP Negeri 3 Trienggadeng. The type of research used in this study is quasi-experimental research using a quantitative approach. In this study there are two variables which consist of independent variables namely motion activity and the dependent variable namely the play approach. The research instrument used in the study used a pedometer. The population in this study were students of SMP Negeri 3 Trienggadeng, samples were taken using cluster random sampling techniques as many as 33 students of class VII. Data analysis using ttest for similar samples. Based on the results of the study, it can be seen the average value and standard deviation of the learning outcomes of the motion activity between the pre-test and posttest. The average learning outcomes of students' motion activities in the pre-test were 840.94 with a standard deviation of 58.778. Post-test obtained the average learning outcomes of student motion activities is 1456.67 with a standard deviation of 168.353. The mean value of the difference between the pre-test and post-test is 615,727 with a standard deviation of 182,971. Based on the results of statistical tests obtained a value of 0,000 , it can be concluded that there is a significant difference between the pre-test and post-test amounting to $73.2 \%$. So the play approach has a significant influence on increasing student motion activity in class VII students of SMP Negeri 3 Trienggadeng.

Keywords: game approach, learning outcomes and physical activity

\section{PENDAHULUAN}

Pendidikan merupakan proses alami yang ada di masyarakat. Dalam perkembangan proses tersebut dapat berlangsung dalam lingkungan keluarga, sekolah, dan masyarakat. Pengertian pendidikan pada system pendidikan nasional adalah usaha untuk menyiapkan peserta didik melalui kegiatan pembelajaran dan latihan.

Pendidikan jasmani, olahraga, dan kesehatan (PJOK) merupakan proses pendidikan yang merupakan pendidikan secara keseluruhan yang pelaksanaannya ditetapkan berdasarkan kurikulum yang ada. Pendidikan jasmani, olahraga, dan kesehatan bertujuan untuk mengembangkan aspek kebugaran jasmani, keterampilan jasmani, pertumbuhan, kecerdasan dan pembentukan watak atau karakter.

Dalam proses pembelajaran
pendidikan jasmani guru harus dapat
mengajarkan berbagai keterampilan gerak
dasar, teknik dan strategi permainan /
olahraga, internalisasi nilai-nilai (sportifitas,
jujur, kerjasama, dan lain-lain) dan
pembiasaan pola hidup sehat.
Pelaksanaannya bukan melalui pengajaran
konvensional di dalam kelas yang bersifat
kajian teoritis, namun melibatkan unsur fisik
mental, intelektual, emosional dan sosial.
Melalui pendidikan jasmani diharapkan
siswa dapat memperoleh berbagai
pengalaman untuk mengungkapkan kesan
pribadi yang menyenangkan, kreatif,
inovatif, terampil, meningkatkan dan
memelihara kesegaran jasmani serta
pemahaman terhadap gerak manusia. Mata
pelajaran Pendidikan Jasmani tidak hanya
identik dengan mata pelajaran yang
menggunakan aktifitas fisik atau


mengeluarkan tenaga saja tetapi sudah saatnya Pendidikan jasmani harus sejajar dengan mata pelajaran yang lain. Dalam hal ini seorang guru pendidikan jasmani dituntut untuk lebih kreatif dalam mengemas paket mata pelajaran pendidikan jasmani, termasuk berusaha untuk memberdayakan dan mengoptimalkan penggunaan sarana dan prasarana yang ada. Seorang guru pendidikan jasmani yang kreatif akan mampu menciptakan sesuatu yang baru, atau memodifikasi yang sudah ada tetapi disajikan dengan cara semenarik mungkin, sehingga anak didik akan merasa senang mengikuti pelajaran pendidkan jasmani yang diberikan

Kenyataan di lapangan menunjuhkan saat pembelajaran pendidikan jasmani masih saja ditemui kegiatan belajar mengajar yang hasil pembelajarannya kurang maksimal. Faktor-faktor yang berpengaruh di antaranya pendekatan pembelajaran, metode, media, atau sumber pembelajaran. Jika kondisi pembelajaran semacam itu dibiarkan berlarut-larut, bukan tidak mungkin kemampuan aktifitas jasmani di kalangan siswa akan terus berada pada tataran yang rendah. Para siswa akan terus-menerus mengalami kesulitan dalam mengekspresikan kemampuan dan minatnya. Begitu juga dengan proses pembelajaran di SMPN 3 Trienggadeng, siswa kurang aktif dalam bergerak khususnya saat mengikuti mata pelajaran pendidikan jasmani. Dan untuk itu perlu solusi yang tepat, salah satunya dengan cara pendekatan bermain, sehingga upaya untuk mengatasi permasalahan dalam pencapaian hasil belajar dapat teratasi. Berdasarkan pengalaman penulis di SMPN 3 Trienggadeng, siswa cenderung kurang aktif bahkan ada siswa yang tidak melakukan kegiatan sama sekali. Ini dikarenakan ada beberapa siswa yang memang berminat pada pelajaran atau kurang mampu pada materi tersebut sehingga mereka merasa bosan dan jenuh dalam mengikuti pembelajaran pendidikan jasmani. Siswa tidak suka dengan pembelajaran pendidikan jasmani yang hanya terpusat pada materi yang membuat pembelajaran terlihat kaku karena kurang adanya variasi dalam pembelajaran. Siswa lebih senang mengikuti pembelajaran pendidikan jasmani yang dimodifikasi ke dalam bentuk permainan-permainan yang menarik, hal ini dipengaruhi oleh karakter siswa yang cenderung masih suka bermain. Oleh sebab itu seorang guru harus bisa membuat pembelajaran pendidikan jasmani menjadi sebuah permainan yang menarik dan menyenangkan, sehingga dapat menarik minat siswa dalam mengikuti pelajaran pendidkan jasmani.

Untuk menciptakan kondisi belajar siswa yang efektif guru harus berusaha mengurangi metode ceramah dan mulai mengembangkan metode lain yang dapat melibatkan siswa secara aktif. Dengan demikian dalam permasalahan ini metode pembelajaran yang tepat menggunakan metode pembelajaran pendekatan bermain, karena karena metode pembelajaran pendekatan bermain merupakan metode belajar yang menggunakan model permainan.

Dengan dasar latar belakang tersebut maka akan diajukan suatu penelitian yang berjudul "Pengaruh Pendekatan Bermain Terhadap Aktivitas Gerak Siswa Dalam Mengikuti Pelajaran Pendidikan Jasmani Siswa Kelas VI SMPN 3 Trienggadeng

\section{METODE}

Penelitian ini menggunakan jenis penelitian eksperimen dengan pendekatan deskriptif kuantitatif. Penelitian eksperimen adalah suatu penelitian yang dilakukan secara ketat dan sistematis untuk mengeahui hubungan sebab akibat antara variabel satu dengan variabel yang lain.

Desain penelitian ini menggunakan eksperimen one group pretest-posttest design, dimana desain ini tidak ada kelompok kontrol, dan subjek tidak ditempatkan secara acak, kelebihan desain ini adalah dilakukannya prestest dan posttest sehingga dapat diketahui dengan pasti perbedaan hasil akibat perlakuan yang diberikan. 
Populasi adalah wilayah generalisasi yang terdiri obyek/subyek yang mempunyai kualitas dan karakteristik tertentu yang ditetapkan oleh peneliti untuk dipelajari dan kemudian ditarik kesimpulannya. (Sugiyono, 2013: 297). Populasi yang diambil dalam penelitian ini adalah siswa SMPN 3 Trienggadeng

Sampel adalah sebagian kecil dari populasi itu. Dalam menentukan penelitian ini, peneliti menggunakan teknik cluster random sampling. Sampel dalam penelitian ini adalah siswa SMPN 3 Trienggadeng kelas VII sebanyak 33 siswa. Teknik pengumpulan data adalah melakukan pretest dengan memberikan pembelajaran kepada siswa kelas seperti biasa tanpa memberikan perlakuan dan melakukan posttest dengan memberikan perlakuan saat proses pembelajaran sedang berlangsung dengan menggunakan instrumen pedometer

\section{HASIL DAN PEMBAHASAN}

Berdasarkan hasil perhitungan selanjutnya deskripsi data dari hasil penelitian dapat dijabarkan lebih lanjut sebagai berikut:

\section{Tabel 1. Distribusi Data Data}

$\begin{array}{lccc}\text { Deskripsi } & \text { Pre-test } & \text { Post-test } & \text { Beda } \\ \text { Rata-rata } & 840,94 & 1456,67 & 615,727 \\ \text { Sd } & 58,787 & 168,353 & 182,971 \\ \text { Median } & 854,00 & 1423,00 & 569,00 \\ \text { Varian } & 3455,871 & 28342,73 & 24886,86 \\ \text { Min } & 60 & 75 & 15 \\ \text { Max } & 70 & 100 & 30 \\ \text { Kenaikan } & & 73,21 \% & \end{array}$

Berdasarkan hasil data maka dapat diketahui bahwa rata-rata data pre-test adalah 840,94 dengan median 854,00, standar deviasi 58,787, nilai paling rendah 60 dan nilai paling tinggi 75 . Sedangkan rata-rata post-test adalah 1456,67dengan median 1423,00, standar deviasi 168,353, nilai paling rendah 75 dan nilai paling tinggi 100. Melihat dari tabel di atas nilai beda antara pre-test dan post-test untuk rata-rata adalah 615,727 , nilai beda standart deviasi antara pre-test dan post-test sebesar 182,971, nilai beda varian antara pre-test dan post-test sebesar 24886,858, beda nilai minimum antara pre-test dan post-test sebesar 56 dan beda nilai maksimum antara pret-test dan post-test sebesar 30. Sehingga dari hasil tersebut dapat dilihat besar peningkatan pada kelompok eksperimen antara pre-test dan post-test sebesar $73,21 \%$ yang berarti bahwa penerapan melalui pendekatan bermain dalam pembelajaran pendidikan jasmani memberikan pengaruh dalam meningkatkan aktifitas gerak

Tabel 2.Uji normalitas

\begin{tabular}{llllll} 
Variabel & N & \multicolumn{1}{c}{ Min } & Sd & KS-Z & Sig. \\
Pre-Test & 33 & 840,94 & 58,79 & 1,07 & 0,20 \\
Post-Test & 33 & 1456,67 & 168,35 & 0,89 & 0,41
\end{tabular}

Dari tabel diatas dapat dijelaskan bahwa nilai (Kolmogorof-Smirnov Z) dan signifikan dari data pre-test dan post-test lebih besar dari nilai $\alpha(5 \%)$ atau 0,05 sehingga diputuskan Ho diterima yang berarti data memenuhi asumsi normal.

Tabel 3. Hasil Uji T

\begin{tabular}{|c|c|c|c|c|c|c|}
\hline $\begin{array}{l}\text { Variab } \\
\text { el }\end{array}$ & $\mathbf{N}$ & Mean & Sd & M Sd & $\mathbf{T}$ & Sig. \\
\hline $\begin{array}{l}\text { Pre- } \\
\text { test }\end{array}$ & $\begin{array}{l}3 \\
3\end{array}$ & 840,94 & 58.79 & 615,7 & 19,3 & 0,0 \\
\hline $\begin{array}{l}\text { Post- } \\
\text { test }\end{array}$ & $\begin{array}{l}3 \\
3\end{array}$ & $\begin{array}{c}1456,6 \\
7\end{array}$ & $\begin{array}{l}168,3 \\
5\end{array}$ & 2 & 3 & 0 \\
\hline
\end{tabular}

Pada tabel terlihat nilai berupa ratarata dan standar deviasi hasil belajar aktivitas gerak antara pre-test dan post-test. Rata-rata hasil belajar pretest aktifitas gerak siswa adalah 840,94 dengan standar deviasi 58,787. Posttest didapat rata-rata hasil belajar aktifitas gerak siswa adalah 1456,67 dengan standar deviasi 168,353. Terlihat nilai mean perbedaan antara pre-test dan post-test adalah 615,727 dengan standar deviasi 182,971 hasil uji statistik didapatkan nilai 0,000 maka dapat disimpulkan ada perbedaan yang signifikan antara pre-test dan post-test 
Dari penjelasan di atas maka peran guru diperlukan terutama untuk memahami dan menerapkan metode pendekatan bermain dalam upaya meningkatkan aktivitas gerak siswa dalam mengikuti pembelajaran pendidikan jasmani.

\section{PENUTUP}

\section{Simpulan}

Terdapat Pengaruh Pendekatan Bermain terhadap aktifitas gerak siswa dalam mengikuti pelajaran pendidikan jasmani dengan besar pengaruh pendekatan bermain terhadap aktifitas gerak siswa adalah sebesar $73,21 \%$

\section{Saran}

Berdasarkan penemuan pada saat penelitian dan simpulan di atas, maka diajukan saran yang diharapkan dapat memperbesar manfaat hasil penelitian ini, adapun saran yang perlu diungkapkan sebagai berikut:

1. Guru tidak cukup hanya memberikan mata pelajaran seperti biasanya namun guru juga perlu memberikan materi melalui pendekatan bermain pada siswa untuk memaksimalkan peningkatan aktifitas gerak pada siswa

2. Dengan menggunakan pendekatan bermain seluruh siswa akan sepenuhnya mengikuti keseluruhan proses pembelajaran dan mengatasi kurangnya gerak siswa dalam mengikuti pembela jaran

\section{DAFTAR PUSTAKA}

Arikunto, S. (2003). Dasar-dasar Evaluasi Pendidikan. Jakarta; Bumi Aksara

Hartati,S.C.Y;Priambodo,AKristiyandaru, A.(2012).Permainan Kecil:ca raefektif mengembangkan fisik,motoric,keterampilan sosial, dan emosional. Malang; Wineka Media http://mariberkawand.blogspot.com/2011/08 /pengertian-pendekatanbermain.html 26/09/2014

Maksum, A. (2009). Statistik Dalam Olahraga.Surabaya;Unesa University Press

$\begin{array}{ll}\text { Dalam 2012). } & \begin{array}{l}\text { Metode Penelitian } \\ \text { Olahraga.Surabaya; }\end{array} \\ \text { Unesa University Press }\end{array}$

Nurhasan dkk.(2005). PetunjukPraktis Pendidikan Jasmani;Bersatu membangun sehat jasmani danrohani. Surabaya;Unesa University Press

Rahyubi, H, (2014). Teori-teori Belajar danAplikasiPembelajaran

Motorik. Majalengka; Nusa Media

Susanto, Eko. 2011.PengaruhModifikasi PermainanTerhadap Hasil Belajar Passing Sepakbola.Sura baya;FIK Unesa Pajaran pendidi kan jasmani. 